\title{
Optical fiber mercury biosensor based on immobilized urease and bromothymol blue onto the alginate-chitosan membrane in the flow-system
}

\author{
Dhony Hermanto $^{1,}{ }^{*}$, Mudasir $^{2}$, Dwi Siswanta ${ }^{2}$, Bambang Kuswandi ${ }^{3}$, Nurul Ismillayli ${ }^{1}$ \\ ${ }^{1}$ Dept. of Chemistry, Faculty of Mathematics and Natural Sciences, University of Mataram \\ Jl. Majapahit 62, Mataram West Nusa Tenggara, Indonesia 83125 \\ ${ }^{2}$ Dept. of Chemistry, Faculty of Mathematics and Natural Sciences, University of Gadjah Mada \\ Jl. Sekip Utara BLS 21, Bulaksumur-Sleman, Yogyakarta 55281, Indonesia \\ ${ }^{3}$ Chemo and Biosensor Group, Faculty of Pharmacy, University of Jember \\ Jl. Kalimantan I/2 Tegalboto Sumbersari, Jember East Java 68121, Indonesia \\ *Corresponding author: dhony.hermanto@unram.ac.id
}

\begin{abstract}
An optical fiber biosensor has been developed for the detection of mercury ion based on inhibition of urease immobilized onto alginate-chitosan membrane, coupled with bromothymol blue (BTB) in the flow system. To get a good performance of the biosensor toward $\mathrm{Hg}$ (II) ion detection, the experimental parameters of the biosensor were optimized. Here, the maximum wavelength was detected at $580 \mathrm{~nm}$, with the optimum response at $\mathrm{pH}$ of 6 . The calibration curve had a dynamic working range at 10 to $500 \mu \mathrm{g} / \mathrm{L}$ of $\mathrm{Hg}(\mathrm{II})$ ion with a detection limit of $12.1 \mu \mathrm{g} / \mathrm{L}$ (equal to $10 \%$ inhibition) and high reproducibility $(\mathrm{RSD}=0.86 \%)$. The regeneration of the biosensor has been performed by the addition of $1 \mathrm{mM}$ ethylenediaminetetraacetic acid (EDTA) solution, in which five-time cycles have been achieved with the inhibition decrease to $9.94 \%$ from the original biosensor response. Applying the biosensor to the real samples showed conformity of results with the reference method, cold vapor atomic absorption spectrometry (CV-AAS). Therefore, this biosensor can be used as a method for routine analysis in the determination of $\mathrm{Hg}$ (II) concentration in an aqueous sample.
\end{abstract}

Keywords: Alginate-chitosan membrane; BTB; $\mathrm{Hg}$ (II) ion; optical fiber biosensor; urease.

\section{Introduction}

Mercury ( $\mathrm{Hg}$ ) as heavy metal, is known as a global pollutant (Driscoll et al., 2013) that is released into the environment from geological and anthropogenic sources. Its compounds that are highly mobile and toxic at trace level (Belluzzi-muiños et al., 2017) cause distress for human and environmental health (Sures, 2004; Urek et al., 2013) and induce many illnesses even death (Nordberg et al., 2000). Hence, a simple and rapid method for mercury detection at trace level in environmental samples is needed (Apilux et al., 2012; Samphao et al., 2012).

The conventional methods for the determination of mercury are atomic absorption spectrometry (AAS) (Nakadi et al., 2020; Szkoda et al., 2006), inductively coupled plasma with mass spectrometry (ICP-MS) (Hofer et al., 2017; Nixon et al., 1999), etc. Another analytical method that has been developed for this purpose is an electrochemical method (Pujol et al., 2014). However, these standard methods require sample preparation, laborious procedure, and sophisticated instrumentation as well as high cost. Alternatively, the optical biosensor offers more benefits over the other existing methods, due to their simple, quick, and inexpensive analysis (Long et al., 2013), particularly for the determination of heavy metal ions in the field. In 
addition, an optical biosensor is a powerful alternative technique, by combining the specificity and sensitivity of biological systems, such as enzymes in small devices.

Enzyme inhibition method in the optical biosensor is commonly used for inhibitor detection, such as heavy metal ion. This method could use a wide range of enzymes that are specifically inhibited by trace concentration of certain metal ions (He et al., 2018; Ilangovan et al., 2016; Turdean, 2011, Shi \& Jiang, 2002). Kuralay et al. (2007) developed an amperometric biosensor based on inhibition of immobilized urease in poly(vinylferrocenium) film for the $\mathrm{Hg}^{2+}$ ion determination and Kuswandi (2003) fabricated a simple optical fiber biosensor for $\mathrm{Hg}$ (II) determination. Here, the determination of $\mathrm{Hg}^{2+}$ by enzyme-based biosensor can be very sensitive but the inhibition of enzymatic reaction by $\mathrm{Hg}^{2+}$ leads to poor selectivity. Other heavy metal ions such as $\mathrm{Fe}^{3+}, \mathrm{Cu}^{2+}, \mathrm{Cr}^{3+}$ were also enzyme inhibitors. Improving the selectivity is important in $\mathrm{Hg}(\mathrm{II})$ determination since these interference ions possibly coexist in a real sample.

Immobilization of enzyme into suitable solid support material is one of the key successes in designing biosensors since this step plays an important role in the overall biosensor performance, including its selectivity. Zeng et al., (2015) developed a sensitive potentiometric biosensor for $\mathrm{Hg}$ (II) determination by using a three-dimensional network structure as a matrix, chitosanpolyvinyl alcohol with glutaraldehyde crosslinker. In this study, a better and more simple preparation network matrix was used, polyelectrolyte complexes (PEC) of alginate-chitosan. Here, carboxylic groups of alginates interact with protonated amine groups of chitosan through ionic interactions to form complexes without the addition of crosslinkers at certain conditions and ratios. It was indicated by FTIR spectra of alginate-chitosan PEC at $1550 \mathrm{~cm}^{-1}\left(\mathrm{NH}_{3}{ }^{+}\right), 1577$ $\mathrm{cm}^{-1,}$ and $1398 \mathrm{~cm}^{-1}$ (-COO-) (Hermanto et al., 2020; Ismillayli et al., 2020; Kulig et al., 2016). This strong ionic bonding was the main interaction inside the network. It has been reported that the immobilization of enzymes onto PEC, maintains higher enzyme activities than original enzymes and it was stable for long periods (Yabuki, 2011). Hence, PEC is a potentially attractive membrane for biosensor application. So far, alginate-chitosan PEC has not been used as an enzyme immobilization matrix in optical biosensor design. In previous studies (Hermanto et al., 2019), this membrane was used as a support material for urease immobilization which showed good characteristics as a matrix. Hence, in this study urease coupled with BTB was immobilized onto the alginate-chitosan membrane. The membrane was used as a biosensor matrix for the determination of $\mathrm{Hg}(\mathrm{II})$ ions using the optical fiber flow injection analysis in aqueous solutions. The optimization for urease immobilization in alginate-chitosan membrane was carried out and the effects of $\mathrm{pH}$ and temperature in the biosensor response as well as stability of biosensor were studied along with biosensor analytical characteristics.

\section{Experimental}

\subsection{Chemicals and instruments}

The urease (E.C. 3.5.1.5.), sodium alginate, and chitosan used to prepare biosensors were purchased from Sigma (St. Lois, USA). Urease $(272 \mathrm{u} / \mathrm{g}$ ) was isolated from jack beans (Type III and U1500), sodium alginate was isolated from brown alga (300-400 cp) and chitosan was isolated from crab shell with 95\% deacetylated. Hydrochloride acid (37\%), glacial acetic acid (98\%), sodium hydroxide, potassium dihydrogen phosphate $\left(\mathrm{KH}_{2} \mathrm{PO}_{4}\right)$, ethylenediaminetetraacetic acid (EDTA), and Bromothymol blue (BTB) were received from Merck (UK). Urea stock solution $(1000 \mu \mathrm{g} / \mathrm{mL})$ was prepared in an aqueous solution. The 
standard metal solutions of $\mathrm{Ag}(\mathrm{I}), \mathrm{Hg}(\mathrm{II}), \mathrm{Cu}(\mathrm{II}), \mathrm{Cd}(\mathrm{II})$, and $\mathrm{Pb}$ (II) (1000 mg/L) (grade of analytical, Merck) were diluted with appropriate buffer solution. Deionized water was used for solutions preparation. An optical fiber USB 2000 spectrometer (Ocean Optic, USA) was used for the reflectance measurements. While all $\mathrm{pH}$ measurements were conducted by using $\mathrm{A} \mathrm{pH}$ meter model IM-20E (TOA Electronics Ltd.).

\subsection{Preparation of membrane}

The membrane was prepared by mixing two polymer solutions consist of chitosan and alginate hydrosols, as described by previous work (Hermanto et al., 2019). The produced membrane was used as solid support of urease and BTB immobilization.

\subsection{Immobilization procedure}

The $3 \mu \mathrm{L}$ alginate-chitosan hydrosol was added to a $1 \mu \mathrm{L}$ phosphate buffer ( $\mathrm{pH}$ 6.5). The buffered mixture was added to $3 \mu \mathrm{L}$ of urease (enzyme solution in phosphate buffer, $\mathrm{pH} 6.5$ ) and $3 \mu \mathrm{L}$ of BTB $(1.5 \mathrm{mg} / \mathrm{mL}$ in ethanol) (Hermanto et al., 2019). Here, maintaining enzyme activity was achieved by using phosphate buffer in the modified hydrosol process. Immediately, the mixture $(10 \mu \mathrm{L})$ was formed in the designed circular mold (i.d.10 mm and $1 \mathrm{~mm} \mathrm{depth}$ ) thinned and flattened using a magnetic stirrer $(300 \mathrm{rpm})$ for 10 seconds then stored for the aging process $\left(5\right.$ days, $4{ }^{\circ} \mathrm{C}$ ). The obtained film was released from the mold and stored in a closed container at $4{ }^{\circ} \mathrm{C}$ until used.

\subsection{Optical biosensor design}

For optical biosensor design, the alginate-chitosan/urease and BTB membrane were packed into a flow cell (i.d. $50 \mathrm{~mm}$ and $50 \mathrm{~mm}$ depth) at room temperature (Figure. 1), then was faced directly to the circular end of a fiber optic bundle probe. The flow-cell device integrated two needles assigned at $120^{\circ}$ opposite each other (stainless-steel, i.d. $1 \mathrm{~mm}$ and $20 \mathrm{~mm}$ length) for the inlet/outlet solution flow with an internal flow cell volume of approximately $20 \mu \mathrm{L}$. The circular bottom end of the flow cell is provided with a PTFE disk for a reflective surface backing. 


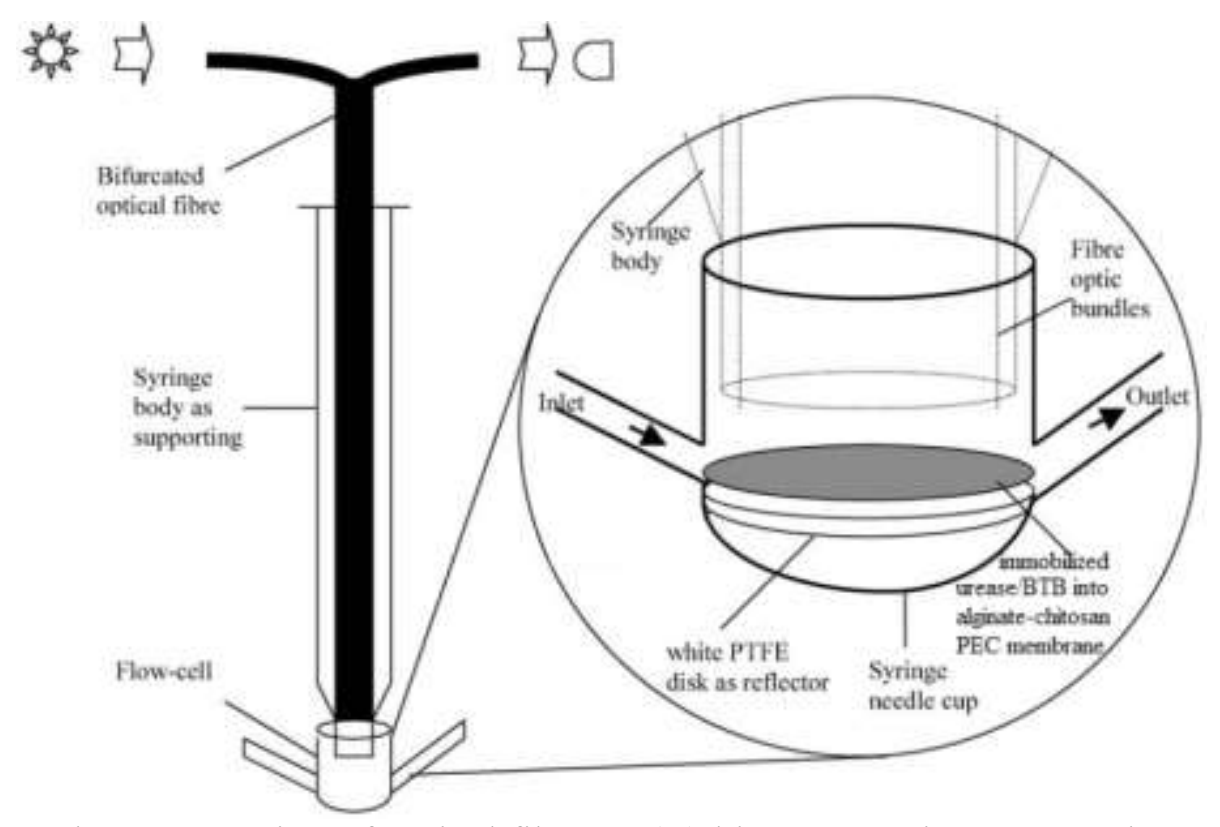

Fig. 1. The construction of optical fiber $\mathrm{Hg}($ II) biosensor using spectrophotometry

\subsection{Flow manifold and measurement procedure}

Flow injection analysis (FIA) has a flow manifold configuration as shown in Figure 2. The FIA system consists of three injection valves (Omnifit 1106) and a four-channel peristaltic pump equipped with a Tygon tube (1.0 mm i.d.). Teflon ${ }^{\circledR}$ tubing was used between all components in the FIA system (FIA 5010, Tecator). In the beginning, the carrier solution of phosphate buffer was pumped and flowed through the FIA system producing a baseline signal. Then, the urea solution was injected manually at injection valve 2 to determine the initial activity of the enzyme without inhibition (Eo). While the $\mathrm{Hg}$ (II) ion in the sample solution was injected into valve 1. After the inhibition, residual enzyme activity was revealed by urea injection, and the inhibition percentage $(\mathrm{Ec})$ was calculated based on the following equation:

Inhibition $(\% I)=[(E o-E c) / E o] \times 100$

Where Eo and Ec are substrate signal intensities without and with inhibitors. After inhibition determination, reactivation solution ( $1 \mathrm{mM}$ EDTA) was injected through injection valve 3 to leach heavy metal ions from urease so that its activity was restored. The same cycle was carried out in other $\mathrm{Hg}(\mathrm{II})$ concentration measurements. The membrane must be washed carefully after the measurement to avoid blockage due to salt precipitation in the buffer solution. 


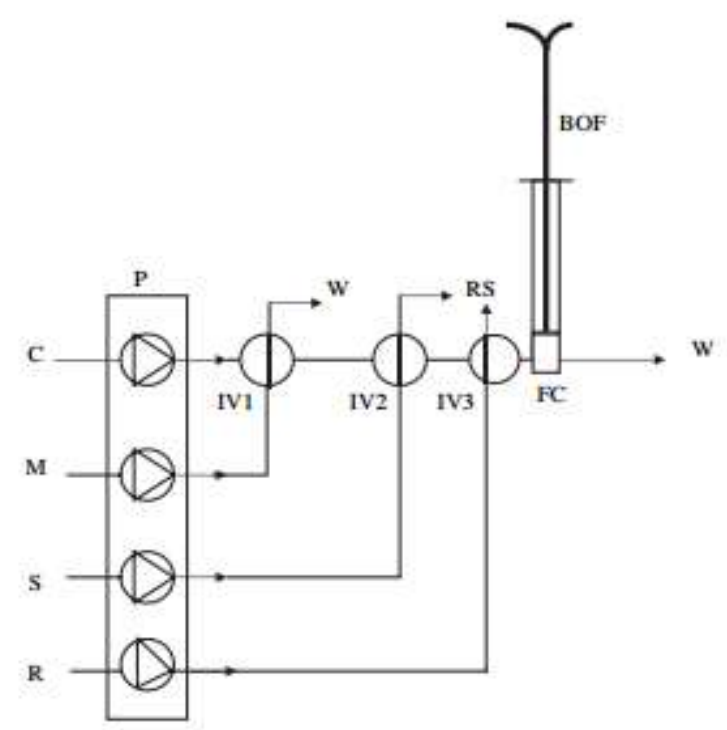

Fig. 2. The flow manifold is used for the measurement of urease-based biosensors for the determination of $\mathrm{Hg}(\mathrm{II})$ ions. $\mathrm{C}$, carrier ( $\mathrm{pH}$ 6.0, $0.1 \mathrm{~N}$ phosphate buffer solution); $\mathrm{M}$, sample (metal ions solution); $\mathrm{S}$, substrate (urea solution); $\mathrm{R}$, regeneration solution (1 mM EDTA solution); P peristaltic pump; IV injection valve; RS reservoir; FC flow-cell; BOF bifurcated optical fibre; W waste.

2.6 Detection of $\mathrm{Hg}(\mathrm{II})$ ions in the real sample

Optical biosensor evaluation for the detection of $\mathrm{Hg}(\mathrm{II})$ in the real samples was carried out on tap water obtained from our lab, river, and seawater from Sekotong district, West Lombok regency, Indonesia. Firstly, water samples were filtered using a syringe filter $(0.22 \mu \mathrm{m})$, then a standard solution of $\mathrm{Hg}$ (II) $20 \mathrm{ppb}$ was added to the sample solution. The reflectance intensity was recorded on the optical fiber spectroscopy at $580.15 \mathrm{~nm}$ using the same measuring conditions. As a comparison, the CV-AAS (GBC HG 300) was also used as the reference method for the determination of $\mathrm{Hg}(\mathrm{II})$ ions in the real water sample.

\section{Results and discussion}

\subsection{Biosensor scheme}

The optical biosensor used the immobilized urease as a bio-catalytic element for the selective substrate. Urease broke carbon-nitrogen bond in urea and release $\mathrm{CO}_{2}, \mathrm{NH}_{3}$, and water as products, according to Equation.1.

$$
\begin{aligned}
& \left(\mathrm{NH}_{2}\right)_{2} \mathrm{CO}_{(\mathrm{aq})}+3 \mathrm{H}_{2} \mathrm{O}_{(\mathrm{l})} \stackrel{\text { urease }}{\rightleftarrows} 2 \mathrm{NH}_{3}(\mathrm{aq})+\mathrm{CO}_{2(\mathrm{~g})}+2 \mathrm{H}_{2} \mathrm{O}_{(\mathrm{l})} \\
& \mathrm{NH}_{3(\mathrm{aq})}+\mathrm{H}_{2} \mathrm{O}_{(\mathrm{l})} \rightleftarrows \mathrm{NH}_{4}^{+}{ }_{(\mathrm{aq})}+\mathrm{OH}_{(\mathrm{aq})}^{-}
\end{aligned}
$$

Ammonia was protonated by water to form $\mathrm{NH}_{4}{ }^{+}$and $\mathrm{OH}^{-}$(Equation 2) and produced an increase in $\mathrm{pH}$. This process was detected by BTB indicator (pKa 7.2) that was showed by 
membrane color change from yellow to green. This process also caused a change in spectra and was used as the optical response. Furthermore, the inhibition measurements were carried out by passing the $\mathrm{Hg}(\mathrm{II})$ ion into the biosensor. The $\mathrm{Hg}(\mathrm{II})$ ion has a strong affinity to sulfhydryl (-SH) group of urease to form $\mathrm{Hg}(\mathrm{II})$-mercaptide as given Equation. 3.

$\mathrm{E}-\mathrm{SH}+\mathrm{Hg}^{2+} \rightleftarrows \mathrm{E}-\mathrm{S}-\mathrm{Hg}$

The inhibition of $\mathrm{Hg}(\mathrm{II})$ ions in urease activity caused the very low rate of urea hydrolysis reaction and even caused loss activity of urease. Consequently, less ammonia was formed and lower $\mathrm{pH}$ change was detected when urease was reacted with urea. It was indicated quantitatively by the decrease in signal intensity at the presence of $\mathrm{Hg}(\mathrm{II})$, as shown in Figure 3 . Since the amount of $\mathrm{Hg}(\mathrm{II})$ ions was proportional to the detected $\mathrm{pH}$ change before and after inhibition, $\mathrm{Hg}$ (II) concentration in the sample can be determined.

As it is illustrated in Figure 3, the maximum wavelength for biosensors was obtained when the signal intensity difference before and after reaction with $\mathrm{Hg}(\mathrm{II})$ ions was the greatest. The signal intensity of the biosensor changed due to the $\mathrm{pH}$ increase, as increasing of ammonium ion (product of urea hydrolysis by the urease). Then, a $\mathrm{pH}$ increase was detected by the BTB indicator.

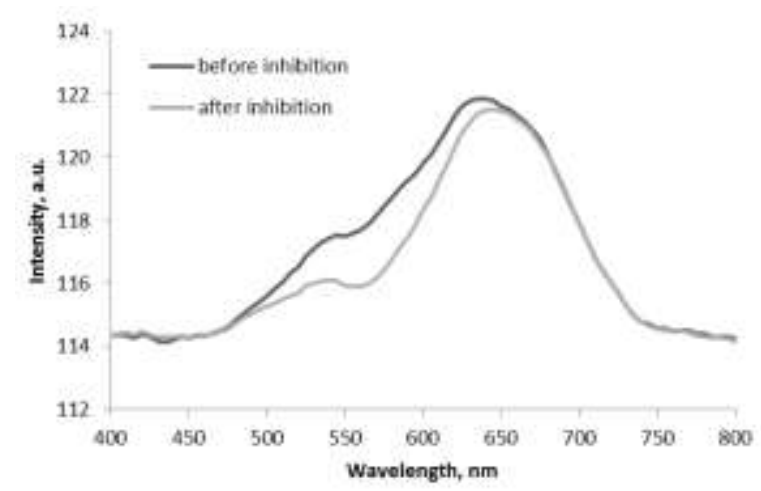

Fig. 3. The BTB spectra (i) before and (ii) after inhibition by $\mathrm{Hg}(\mathrm{II})$ ions.

Here, the color changed from yellow to green leading to a decrease in the reflected signal intensity at $580.15 \mathrm{~nm}$. This aspect is important since the $\mathrm{pH}$ working range of the $\mathrm{pH}$ indicator fits very well with the $\mathrm{pH}$ change associated with the enzyme-substrate reaction. On the other hand, the plain shape of the $\mathrm{pH}$ indicator allowed easy access for the analyte, which in turn, resulted in high sensitivity of $\mathrm{pH}$ indicator to the net of $\mathrm{pH}$ change. Furthermore, the matrix effect on $\mathrm{pH}$ indicators had been minimized by using a buffer to maintain the stability of the biosensor response. It means that $\mathrm{pH}$ change only correlated to the $\mathrm{Hg}$ (II) ion concentration and not to other parameters (Kuswandi \& Suwandari, 2007).

\subsection{Optimum parameters}

The optimization of the experimental parameters is an essential step in the analytical characteristics of the mercury biosensor performance. Table 1 shows some of the investigated experimental parameters and their optimum value. It was found that $\mathrm{pH} 6$ of the buffer solution was optimum and was used for further measurement. 
The enzymatic reaction will occur effectively when the substrate concentration is proportional to enzyme activity. Therefore, optimization of urea concentration as the substrate is needed to obtain good reproducibility results. The range of urea concentration was 10 to $100 \mathrm{mM}$. Here, the concentration of $75 \mathrm{mM}$ was optimum for the urea concentration and used for further measurements.

The rate of enzyme catalysis can be affected significantly even with a small change in their chemical environment. In this study, both urease and BTB were immobilized into the alginate chitosan membrane. To interact with the enzyme, the substrate must diffuse and penetrate the membrane. A certain period is needed, hence maximum change is obtained. Substrate flow at a controlled rate to ensure urea hydrolysis produces ammonium and hydroxy ions which induce a color change of the membrane. In this case, the flow rate of $10 \mathrm{~mL} / \mathrm{min}$ produced a relatively constant response of biosensors toward the substrate. Then, this flow rate was used for further measurements.

The inhibition time was also optimized to provide optimum time for binding of $\mathrm{Hg}$ (II) ions with the active site of urease. It has been performed bypassing of $\mathrm{Hg}$ (II) solution toward the biosensor, and it was found that 7 min was the optimum time for inhibition. Reaction temperature also affected on blank and inhibition signal of the biosensor. Here, the temperature at $25^{\circ} \mathrm{C}$ was the moderate temperature in this enzymatic inhibition reaction. Since at higher temperatures, immobilized enzyme activity decreased. Temperature affects the alginate-chitosan membrane as solid support for the immobilized urease and BTB, which cause small leakage of urease and BTB.

Table 1. Optimization of biosensor parameters

\begin{tabular}{lcc}
\hline \multicolumn{1}{c}{ Parameter } & Range & Optimum \\
\hline $\mathrm{pH}$ & $5-8$ & 6 \\
Substrate/Urea $(\mathrm{mM})$ & $10-100$ & 75 \\
Flow Rate $(\mathrm{mL} / \mathrm{min})$ & $5-15$ & 10 \\
Inhibition Time $(\mathrm{min})$ & $4-8$ & 7 \\
Temperature $\left({ }^{\circ} \mathrm{C}\right)$ & $25-35$ & 25 \\
\hline
\end{tabular}

\subsection{Analytical characteristics}

By applying optimized experimental parameters, dynamic response for $\mathrm{Hg}(\mathrm{II})$ ions was observed as the change of signal intensity reflected before and after inhibition at $580 \mathrm{~nm}$. The calibration curve was made by measuring biosensor response to urease activity due to the presence of $\mathrm{Hg}$ (II) ions. For example, series of $\mathrm{Hg}(\mathrm{II})$ solutions at 10-500 $\mu \mathrm{g} / \mathrm{L}$ interval concentration were passed into a biosensor system with three replications (Figure 4). First, the biosensor was injected buffer to give the baseline signal, followed by urea to give the blank signal. Then, a sample contained $\mathrm{Hg}$ (II) ions was injected, followed by urea to give the inhibited signal. To regenerate the inhibited signal, the regeneration solution (EDTA) was injected to recover the immobilized enzyme activity. However, the inhibited urease cannot be regenerated fully $(100 \%$ of its enzyme activity) due to strong metal-urease binding that was considered an irreversible reaction. This might be the reason for increasing response at EDTA regeneration. From Figure 4, the relationship between $\mathrm{Hg}^{2+}$ ion concentration and \% urease inhibition was described in Table 2 . 


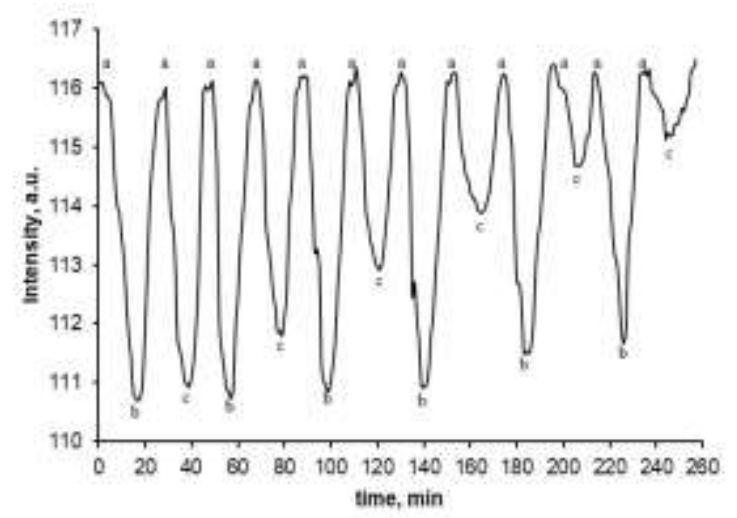

Fig. 4. The average response curve of inhibited urease biosensor by $\mathrm{Hg}(\mathrm{II})$ in triplicate mode (in this case toward 10, 20, 50, 100, 200, $500 \mu \mathrm{g} / \mathrm{L} \mathrm{Hg}$ (II)) and its regeneration using EDTA; (a) substrate; (b) $\mathrm{Hg}(\mathrm{II})$ ions (c) regeneration.

Table 2. Evaluation of the urease inhibition by $\mathrm{Hg}(\mathrm{II})$ in biosensor

\begin{tabular}{cccccccc}
\hline $\begin{array}{c}\left.\mathrm{HHg}^{2+}\right] \\
(\mu \mathrm{g} / \mathrm{L})\end{array}$ & $\log \left[\mathrm{Hg}^{2+}\right]$ & \multicolumn{3}{c}{ \% Inhibition } & \multirow{2}{*}{ Average } & STDEV & \multirow{2}{*}{$\mathrm{RSD}$} \\
\cline { 3 - 7 } 10 & 1.000 & 3.235 & 3.459 & 3.430 & 3.375 & 0.122 & 3.617 \\
20 & 1.301 & 19.335 & 19.195 & 19.118 & 19.216 & 0.110 & 0.573 \\
50 & 1.699 & 36.289 & 36.308 & 36.186 & 36.261 & 0.065 & 0.180 \\
100 & 2.000 & 55.406 & 55.332 & 55.643 & 55.460 & 0.162 & 0.293 \\
200 & 2.301 & 63.162 & 63.431 & 63.238 & 63.277 & 0.139 & 0.220 \\
500 & 2.699 & 73.529 & 73.205 & 73.580 & 73.438 & 0.203 & 0.277 \\
\hline & & & & & & Average & 0.860 \\
\end{tabular}

By evaluating the inhibition degree against the concentration of $\mathrm{Hg}$ (II) ions, calibration curves were plotted. For $\mathrm{Hg}$ (II) concentration intervals from 10 to $500 \mu \mathrm{g} / \mathrm{L}$, the logarithmic curve was obtained as given in Figure 5. Based on this Figure, a linear correlation was generated by plotting \% inhibition of urease versus $\log \mathrm{Hg}(\mathrm{II})$ concentration to obtain a correlation coefficient (r) of 0.9778 as seen in Figure 6. The detection limit determined by inhibition of $\mathrm{Hg}(\mathrm{II})$ to the enzyme at $10 \%\left(I_{10 \%}\right)$ was $12.1 \mu \mathrm{g} / \mathrm{L}$ of $\mathrm{Hg}(\mathrm{II})$ ions. Shi \& Jiang (2002) have developed a dip and read test strip for mercury determination based on urease inhibition with cellulose acetate membrane as a matrix. It was observed that $0.2 \mu \mathrm{g} / \mathrm{L}$ mercury can be detected with a detection range of $0.2-200 \mu \mathrm{g} / \mathrm{L}$. This value indicated lower LOD than this proposed biosensor. However, this biosensor has the advantage over a wider linear range of 10 to 500 $\mu \mathrm{g} / \mathrm{L}$.

Biosensor reproducibility is one of the influential analytical performances. The reproducibility of the proposed biosensor was presented as the coefficient of variation (CV) or relative standard deviation (RSD) toward the determination of standard solutions of $\mathrm{Hg}$ (II) ions $(\mathrm{n}=3)$ using the same alginate-chitosan membrane in the concentration range 10 to $500 \mu \mathrm{g} / \mathrm{L}$. The obtained reproducibility biosensor (RSD) was $0.86 \%$ (Table 2), meaning that the reproducibility was good. 


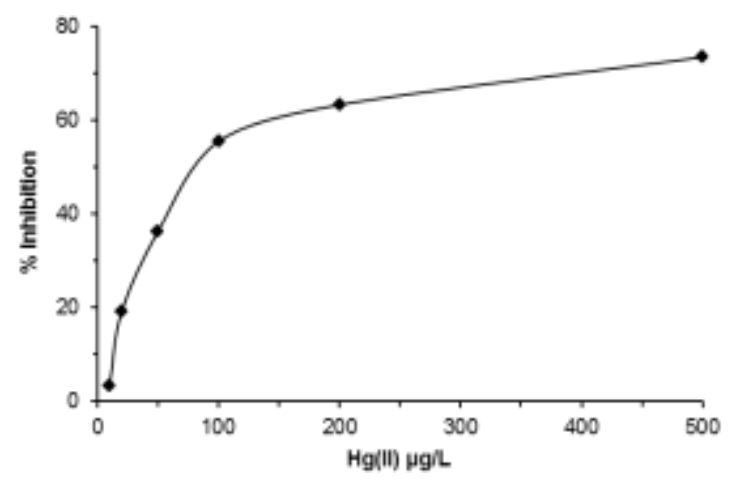

Fig. 5. The calibration curve of urease inhibition vs concentration of $\mathrm{Hg}(\mathrm{II})$.

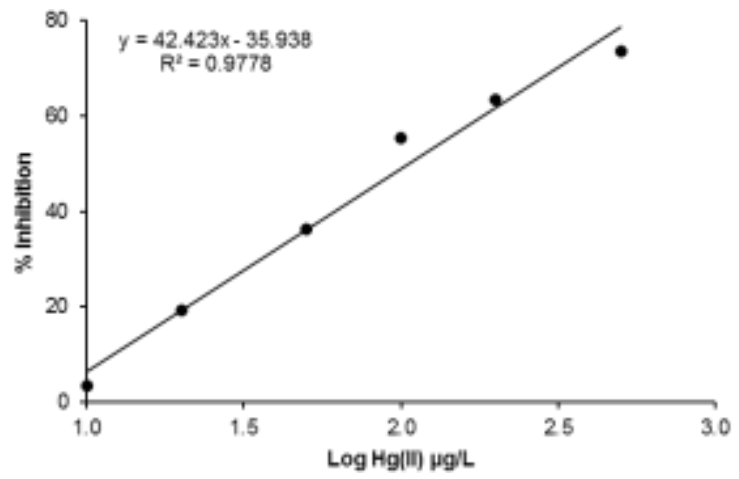

Fig. 6. The calibration curve of urease inhibition vs log concentration of $\mathrm{Hg}(\mathrm{II})$.

The enzyme-based biosensor that has been inhibited by $\mathrm{Hg}(\mathrm{II})$ ions could be regenerated by EDTA as a reactivation agent. Here, it was found that $1 \mathrm{mM}$ of EDTA solution was sufficient to reactivate the enzyme again. The stability of the biosensor is determined by measuring the decreasing enzyme activity during the period of investigation within one week. Besides inhibition caused by the metal ions, the immobilized enzyme activity also decreased during the storage at room temperature $\left(25^{\circ} \mathrm{C}\right)$. While the biosensor was not used, the immobilized urease and BTB into alginate-chitosan membrane was stored in the refrigerator $\left(4^{\circ} \mathrm{C}\right)$. However, the reactivation or regeneration of the proposed biosensor was achieved up to five time cycles, since the data showed that enzyme activity decreased $<10 \%$ after five times used. This might be due to the reactivation effect, such as hysteresis, which implies the biosensor stability during the measurements of $\mathrm{Hg}(\mathrm{II})$ ions. The biosensor selectivity was determined by adding several potentially interfering ions commonly found in water samples with varying concentrations, such as $\mathrm{Pb}(\mathrm{II}), \mathrm{Cu}(\mathrm{II}), \mathrm{Cd}(\mathrm{II})$, and $\mathrm{Ag}(\mathrm{I})$ at $100 \mu \mathrm{g} / \mathrm{L}$. Figure 7 illustrates that the inhibitory value of interference ions $(\mathrm{Pb}(\mathrm{II}), \mathrm{Cu}(\mathrm{II})$, and $\mathrm{Cd}(\mathrm{II})$ ) compared to a blank (without inhibition) was very small $(<5 \%)$. This indicates that these heavy metal ions at this concentration $(100 \mu \mathrm{g} / \mathrm{L})$ did not significantly cause interference. However, only $\operatorname{Ag}(\mathrm{I})$ ions caused a relatively large interference at this concentration compared with other heavy metal ions tested. This might be because $\operatorname{Ag}(\mathrm{I})$ ions have a similar inhibition effect to $\mathrm{Hg}$ (II) ions, where it will also affect the inhibition of urease activity, particularly at the high concentrations (Azmi et al., 2012). 


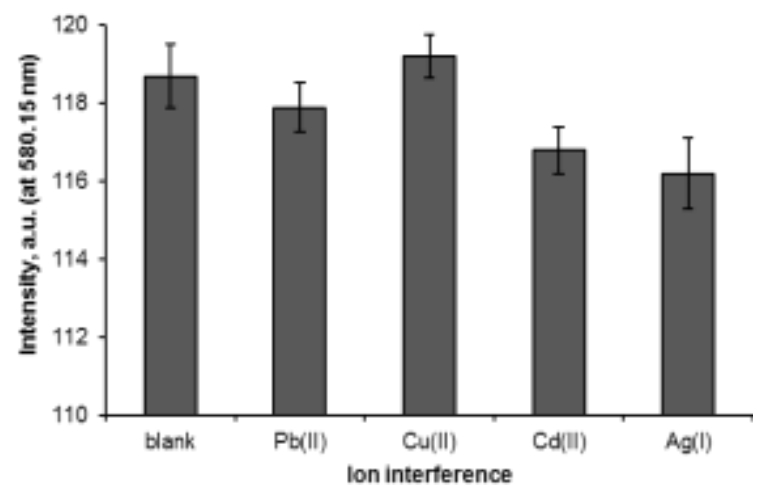

Fig. 7. The biosensor responses toward other heavy metals ions

Determination of $\mathrm{Hg}(\mathrm{II})$ ions in real water samples were carried out using the certified reference method. Here, the sample was spiked with a concentration of $\mathrm{Hg}$ (II) ions of $20 \mathrm{ppb}$. The results of the $\mathrm{Hg}$ (II) ions determination are summarized in Table 3. Table 3 shows the measured $\mathrm{Hg}$ (II) sample concentration values corrected with the added standard $\mathrm{Hg}$ (II) solution. The high concentration of $\mathrm{Hg}(\mathrm{II})$ in the Sekotong seawater sample is related to the high activity of gold processing waste disposal using mercury as gold extractor (amalgamation) into rivers that flow into the sea. The developed optical biosensor has similar results for the determination of $\mathrm{Hg}(\mathrm{II})$ in the real water samples with the reference method using the CV-AAS. AAS is an AOAS official method for determining the metal concentration and is commonly used (Arshad et al., 2020). By using statistical analysis (t-test), it was obtained that there was no significant difference for both methods. Thus, It can be stated that the result of the proposed biosensor measurement has good conformity with the reference method (AAS).

Table 3. Measurement of $\mathrm{Hg}$ (II) concentration in aquatic samples

\begin{tabular}{cccc}
\hline Sample & Various Water Samples & $*$ The biosensor $/ \mathrm{ppb}$ & $*$ AAS $(\mathrm{std} \mathrm{Hg}(\mathrm{II})) / \mathrm{ppb}$ \\
\hline 1 & Buffer & 0.00 & 0.00 \\
2 & Tap water & 0.00 & 0.00 \\
3 & River water & $0.003 \pm 0.003$ & $0.000 \pm 0.000$ \\
4 & Seawater & $44.95 \pm 0.163$ & $40.23 \pm 0.002$ \\
\hline
\end{tabular}

*average of triplicate measurements.

\section{Conclusions}

In the present work, the optical biosensor based on immobilized urease and BTB onto alginatechitosan membran had good analytical performance and rapid response towards $\mathrm{Hg}$ (II) ions in the sample solution. In addition, biosensors could be reused up to five-time by treatment of 1 mM EDTA solution. The result of $\mathrm{Hg}$ (II) measurement in the real water samples showed a good agreement with the reference method (CV-AAS) based on statistical analysis. Hence, the proposed optical biosensor is a reliable alternative method for the simple and rapid determination of $\mathrm{Hg}(\mathrm{II})$ ions in the aqueous samples. 


\section{ACKNOWLEDGEMENTS}

The authors are grateful to DRPM, the Minister of Research Technology, and Dikti, Republic of Indonesia (KEMENRISTEK-DIKTI) for the research funding through doctoral dissertation research grand decree number 65F/SPP-PDDI/UN18.12/PL/2016.

\section{References}

Apilux, A., Siangproh, W., Praphairaksit, N. \& Chailapakul, O. (2012). Simple and rapid colorimetric detection of $\mathrm{Hg}$ (II) by a paper-based device using silver nanoplates. Talanta, 97:388-394.

Arshad, Z., Abrar, A., Nosheen, S., \& Mughal, T. (2020). Determining cadmium levels in herbal tooth powders purchased from street markets in Lahore, Pakistan. Kuwait Journal of Science, 47(1): 79-85.

Azmi, N.E., Abdullah, J., Ahmad, M., Sidek, H., Heng, L.Y. \& Rahman, S.A. (2012). An optical-based biosensor for the determination of ammonium in an aqueous environment. American Journal of Analytical Chemistry, 3(5): 364-370.

Belluzzi-muiños, M., Dol, I. \& Pistón, M. (2017). A low-cost device for sample introduction and determination of mercury by Cold Vapour Atomic Absorption Spectrometry-application for irrigation water and paddy soil. Brazillian Journal of Analytical Chemistry, 4(14):34-43.

Driscoll, C.T., Mason, R.P., Chan, H.M., Jacob, D.J. \& Pirrone, N. (2013). Mercury as a global pollutant: sources, pathways, and effects. Environmental Science and Technology, 47(10):4967-4983.

He, L., Lu, Y., Wang, F., Gao, X., Chen, Y. \& Liu, Y. (2018). Bare eye detection of Hg (II) ions based on enzyme inhibition and using mercaptoethanol as a reagent to improve selectivity. Microchimica Acta, 185(3):1-8.

Hermanto, D., Kuswandi, B., Siswanta, D. \& Mudasir, M. (2019). Inhibitive determination of $\mathrm{Hg}$ (II) in aqueous solution using urease amperometric biosensor. Indonesian Journal of Chemistry, 19(3):786-795.

Hermanto, D., Mudasir, M., Siswanta, D., Kuswandi, B. \& Ismilayli, N. (2019). Polyelectrolyte complex (PEC) of the alginate-chitosan membrane for immobilizing urease. Journal of Mathematics and Fundamental Sciences, 51(3):309-319.

Hermanto, D., Mudasir, M., Siswanta, D., Kuswandi, B. \& Ismilayli, N. (2020). The preparation and characterization of alginate-chitosan membranes as solid support for btb and urease entrapment. Molekul, 15(1):40-47.

Hofer, I., Gremaud, M., Marchese, A. \& Le Bouhellec, S. (2017). Determination of mercury in aerosol by inductively coupled plasma mass spectrometry. De Gruyter Open, 27(8):186-194. 
Ilangovan, R., Daniel, D., Krastanov, A., Zachariah, C. \& Elizabeth, R. (2016). Enzymebased biosensor for heavy metal ions determination. Biotechnology \& Biotechnological Equipment, 20(1):184-189.

Ismillayli, N., Hadi, S., Dharmayani, N. K. T., Sanjaya, R. K., \& Hermanto, D. (2020). Characterization of the alginate-chitosan membrane as potential edible film. In IOP Conference Series: Materials Science and Engineering 833: 1-6.

Kulig, D., Zimoch-Korzycka, A., Jarmoluk, A., \& Marycz, K. (2016). Study on alginatechitosan complex formed with different polymers ratio. Polymers, 8(5):1-17.

Kuralay, F., Ozy, H. \& Yıldız, A. (2007). Inhibitive determination of $\mathrm{Hg}^{2+}$ ion by an amperometric urea biosensor using poly (vinylferrocenium) film. Enzyme and Microbial Technology 40: 1156-1159.

Kuswandi, B. (2003). Simple optical fiber biosensor based on immobilized enzyme for monitoring of trace heavy metal ions. Analytical and Bioanalytical Chemistry, 376(7):11041110 .

Kuswandi, B. \& Suwandari, N.W. (2007). A simple and sensitive flow injection optical fiber biosensor based on immobilized enzyme for monitoring of pesticides. Sensors \& Transducers, 76(2):978-990.

Long, F., Zhu, A. \& Shi, H. (2013). Recent advances in optical biosensors for environmental monitoring and early warning. Sensors, 13(10):13928-13948.

Nakadi, F.V., Garde, R., da Veiga, M.A.M.S., Cruces, J. \& Resano, M. (2020). A simple and direct atomic absorption spectrometry method for the direct determination of $\mathrm{Hg}$ in dried blood spots and dried urine spots was prepared using various microsampling devices. Journal of Analytical Atomic Spectrometry, 35:136-144.

Nixon, D.E., Burritt, M.F. \& Moyer, T.P. (1999). The determination of mercury in whole blood and urine by inductively coupled plasma mass spectrometry. Spectrochimica Acta Part B: Atomic Spectroscopy, 54(8):1141-1153.

Nordberg, G., Jin, T., Leffler, P., Svensson, M., Zhou, T. \& Nordberg, M. (2000). Metallothioneins and diseases with special reference to cadmium poisoning. Analusis, 28:396400.

Pujol, L., Evrard, D., Groenen-Serrano, K., Freyssinier, M., Ruffien-Cizsak, A. \& Gros, P. (2014). Electrochemical sensors and devices for heavy metals assay in water. Frontiers in Chemistry, 2(4):1-24.

Samphao, A., Rerkchai, H., Jitcharoen, J., Nacapricha, D. \& Kalcher, K. (2012). Indirect determination of mercury by inhibition of glucose oxidase immobilized on a carbon paste 
electrode. International Journal of Electrochemical Science, 7:1001-1010.

Shi, G. Q. \& Jiang, G. (2002). A dip-and-read test stript for determination of mercury(II) ion in an aqueous sample based on urease activity inhibition. Analytical Sciences 18: 1215-1219.

Sures, B. (2004). Environmental parasitology: relevancy of parasites in monitoring environmental pollution. Trends in Parasitology, 20(4):170-177.

Szkoda, J., Żmudzki, J.A.N. \& Grzebalska, A. (2006). Determination of total mercury in biological material by atomic absorption spectrometry method. Mercury, 50:363-366.

Turdean, G. L. (2011). Design and development of biosensors for the detection of heavy metal toxicity. International Journal of Electrochemistry, 2011:1-15.

Urek, Š. K., Frančič, N., Turel, M. \& Lobnik, A. (2013). Sensing heavy metals using mesoporous-based optical chemical sensors. Journal of Nanomaterials, 2013:1-13.

Yabuki, S. (2011). Polyelectrolyte complex membranes for immobilizing biomolecules and their applications to bio-analysis. Analytical Sciences, 27:695-702.

Zeng, X., Liu, J., Zhang, Z. \& Kong, S. (2015). Sensitive and selective detection of mercury ions by a potentiometric biosensor based on urease immobilized in chitosan - poly (vinyl alcohol) hydrogel film. International Journal of Electrochemical Science, 10:8344-8352.

$\begin{array}{lr}\text { Submitted: } & 23 / 04 / 2020 \\ \text { Revised: } & 03 / 02 / 2021 \\ \text { Accepted: } & 06 / 02 / 2021 \\ \text { DOI: } & 10.48129 / \text { kjs.v49i1 } \\ \text { DO400 }\end{array}$ 